\title{
ANALISIS FAKTOR-FAKTOR YANG MEMPENGARUHI KESEMBUHAN PASIEN PENYAKIT FLU BURUNG
}

\author{
Yuciana Wilandari dan Diah Safitri \\ Staf Pengajar Prodi Statistika Jurusan Matematika FMIPA UNDIP
}

\begin{abstract}
Avian influenza is contagion which caused by influenza virus type $\mathrm{H} 5 \mathrm{~N} 1$ often cause death. Avian influenza anticipated to be influenced by gender, age, epidemiology and case, to know the factors have a significant effect used by independent test. is later on made model of regresi binary logistics. Then obtained by factor having an effect is case and epidemiology, that is made regression logistics model. Someone which including case of suspect to be able to have probability recover bigger than someone which including confirmation case, someone which contact with dead an avian to be able to have probability recover smaller than someone which no contact.
\end{abstract}

Keywords: Binary Logistics, Avian Influenza

\section{Pendahuluan}

Flu burung merupakan salah satu penyakit yang sangat ditakuti, karena sering menyebabkan kematian. Penyakit ini adalah penyakit menular yang disebabkan oleh virus influenza yang ditularkan oleh unggas yang dapat menyerang manusia. Nama lain dari penyakit ini antara lain avian influenza. Di Indonesia jumlah unggas yang mati akibat wabah penyakit flu burung di 10 propinsi di Indonesia sangat besar yaitu 3.842.275 ekor $(4,77 \%)$ dan yang paling tinggi jumlah kematiannya adalah propinsi Jawa Barat (1.541.427 ekor). Pada 21 Juli 2005, penyakit flu burung telah merenggut tiga orang nyawa warga Tangerang Banten. Hal ini didasarkan pada hasil pemeriksaan laboratorium Badan Penelitian dan Pengembangan Depkes Jakarta dan laboratorium rujukan WHO di Hongkong. Hingga 6 Juni 2007, WHO telah mencatat sebanyak 310 kasus dengan 189 kematian pada manusia ${ }^{[6]}$. Melihat kenyataan ini seyogyanya masyarakat mewaspadai adanya penyakit flu burung, namun tidak perlu sampai timbul kepanikan. Karena itulah tulisan ini dibuat untuk mengetahui faktor-faktor apa saja yang mempengaruhi kesembuhan pasien yang menderita penyakit flu burung dan bagaimana model regresi logistiknya, sehingga dapat diketahui peluang kesembuhan pasien tersebut.

\section{Gambaran Umum Penyakit Flu Burung}

Penyakit flu burung atau flu unggas (Avian influenza) adalah suatu penyakit menular yang disebabkan oleh virus influenza tipe A dan ditularkan oleh unggas. Penyakit flu burung yang disebabkan oleh virus avian infuenza jenis $\mathrm{H} 5 \mathrm{~N} 1$ pada unggas dikonfirmasikan telah terjadi di Republik Korea, Vietnam, Jepang, Thailand, Kamboja, Taiwan, Laos, China, Indonesia dan Pakistan. Sumber virus diduga berasal dari migrasi burung dan transportasi unggas yang terinfeksi ${ }^{[2]}$. Virus influenza termasuk famili Orthomyxoviridae. Virus influenza tipe A dapat berubah-ubah bentuk (Drift, Shift), dan dapat menyebabkan epidemi dan pandemic, yang terdiri dari Hemaglutinin $(\mathrm{H})$ dan Neuramidase $(\mathrm{N})$, kedua huruf ini digunakan sebagai identifikasi kode subtipe flu burung yang banyak jenisnya. Pada manusia hanya terdapat jenis H1N1, H2N2, H3N3, H5N1, H9N2, H1N2, H7N7. Sedangkan pada binatang H1-H5 dan N1-N9. Strain yang sangat 
virulen/ganas dan menyebabkan flu burung adalah dari subtipe A H5N1. Virus tersebut dapat bertahan hidup di air sampai 4 hari pada suhu $22^{\circ} \mathrm{C}$ dan lebih dari 30 hari pada $0^{0} \mathrm{C}$. Virus akan mati pada pemanasan $60^{\circ} \mathrm{C}$ selama 30 menit atau $56^{\circ} \mathrm{C}$ selama 3 jam dan dengan detergent, desinfektan misalnya formalin, serta cairan yang mengandung iodine ${ }^{[2]}$.

Gejala flu burung dapat dibedakan pada unggas dan manusia. Pada unggas gejalanya adalah jengger berwarna biru, borok dikaki, kematian mendadak. Sedangkan pada manusia gejalanya adalah demam (suhu badan diatas $38^{\circ} \mathrm{C}$ ), batuk dan nyeri tenggorokan, radang saluran pernapasan atas, pneumonia, infeksi mata, nyeri otot. Masa inkubasi pada unggas : 1 minggu dan pada manusia : 1-3 hari , masa infeksi 1 hari sebelum sampai 3-5 hari sesudah timbul gejala. Sedangkan pada anak sampai 21 hari ${ }^{[2]}$.

Pada manusia yang termasuk penyakit ada 3 kasus yaitu :

1. Kasus Suspect : adalah seseorang yang menderita ISPA dengan gejala demam (temp $\geq 38^{\circ} \mathrm{C}$ ), batuk dan atau sakit tenggorokan dan atau ber-ingus serta dengan salah satu keadaan; seminggu terakhir mengunjungi petemakan yang sedang berjangkit klb flu burung, kontak dengan kasus konfirmasi flu burung dalam masa penularan dan bekerja pada suatu laboratorium yang sedang memproses spesimen manusia atau binatang yang dicurigai menderita flu burung.

2. Kasus Probable : adalah kasus suspect disertai salah satu keadaan; bukti laboratorium terbatas yang mengarah kepada virus influenza A (H5N1), misal : Test HI yang menggunakan antigen $\mathrm{H} 5 \mathrm{~N} 1$, dalam waktu singkat berlanjut menjadi pneumonialgagal pernafasan/ meninggal, terbukti tidak terdapat penyebab lain.

3. Kasus Konfirmasi : adalah kasus suspect atau "probale" didukung oleh salah satu hasil pemeriksaan laboratorium; Kultur virus influenza H5N1 positip, PCR influenza (H5) positip, Peningkatan titer antibody H5 sebesar 4 kali.

Penularan Flu burung (H5N1) pada unggas terjadi secara cepat dengan kematian tinggi. Penyebaran penyakit ini terjadi diantara populasi unggas satu perternakan, bahkan dapat menyebar dari satu perternakan ke peternakan daerah lain. Sedangkan penularan penyakit ini kepada manusia dapat melalui udara yang tercemar virus tersebut, baik yang berasal dari tinja atau sekreta unggas terserang Flu Burung. Adapun orang yang mempunyai resiko besar untuk terserang flu burung (H5N1) ini adalah pekerja peternakan unggas, penjual dan penjamah unggas. Hal lain, belum ada bukti terjadi penularan dari manusia ke manusia. Disamping itu, belum adanya bukti penularan pada manusia melalui daging unggas yang dikonsumsi. Upaya pencegahan penularan dilakukan dengan cara menghindari bahan yang terkontaminasi tinja dan sekret unggas, dengan tindakan sebagai berikut:

- Setiap orang yang berhubungan dengan bahan yang berasal dari saluran pencernaan unggas harus menggunakan pelindung (masker, kacamata renang)

- Bahan yang berasal dari saluran cerna unggas seperti tinja harus ditatalaksana dengan baik ( ditanam / dibakar) agar tidak menjadi sumber penularan bagi orang disekitarnya.

- Alat-alat yang dipergunakan dalam peternakan harus dicuci dengan desinfektan

- Kandang dan tinja tidak boleh dikeluarkan dari lokasi peternakan

- Mengkonsumsi daging ayam yang telah dimasak pada suhu $80^{\circ} \mathrm{C}$ selama 1 menit, sedangkan telur unggas perlu dipanaskan pada suhu $64^{\circ} \mathrm{C}$ selama 5 menit. 
- Melaksanakan kebersihan lingkungan.

- Melakukan kebersihan diri ${ }^{[3]}$

Pengobatan bagi penderita flu burung adalah:

- Oksigenasi bila terdapat sesak napas

- Hidrasi dengan pemberian cairan parenteral (infus), pemberian obat anti virus oseltamivir $75 \mathrm{mg}$ dosis tunggal selama 7 hari

- Amantadin diberikan pada awal infeksi , sedapat mungkin dalam waktu 48 jam pertama selama 3-5 hari dengan dosis $5 \mathrm{mg} / \mathrm{kg}$ BB perhari dibagi dalam 2 dosis. Bila berat badan lebih dari $45 \mathrm{~kg}$ diberikan $100 \mathrm{mg} 2$ kali sehari $^{[6]}$

\section{Model Regresi Logistik Biner}

Model regresi logistik biner digunakan untuk menganalisa hubungan antara satu variabel respon (Y) dan satu atau lebih variabel penjelas $(\mathrm{X})$, dengan variabel responnya bersifat kategori yaitu bernilai 1 untuk menyatakan keberadaan sebuah karakteristik dan bernilai 0 untuk menyatakan ketidakberadaan sebuah karakteristik. Sedangkan variabel penjelasnya dapat bersifat kategori ataupun kontinu

Bentuk umum model logit $\pi\left(\mathrm{x}_{\mathrm{i}}\right)$ adalah:

$$
\ln \left(\frac{\pi\left(x_{i}\right)}{1-\pi\left(x_{i}\right)}\right)=\beta_{0}+\beta_{1} x_{1 i}+\ldots+\beta_{p} x_{p i}
$$

dengan $\pi\left(\mathrm{x}_{\mathrm{i}}\right)=\mathrm{P}\left(\mathrm{Y}_{\mathrm{i}}=1 \mid \mathrm{X}=\mathrm{x}_{\mathrm{i}}\right)$ dan $\pi\left(\mathrm{x}_{\mathrm{i}}\right)=\frac{e^{\beta_{0}+\beta_{1} x_{1 i}+\ldots+\beta_{p} x_{p i}}}{1+e^{\beta_{0}+\beta_{1} x_{1 i}+\ldots+\beta_{p} x_{p i}}}$

Jika $g\left(x_{\mathrm{i}}\right)=\beta_{0}+\beta_{1} \mathrm{x}_{1 \mathrm{i}}+\ldots+\beta_{\mathrm{p}} \mathrm{x}_{\mathrm{pi}}$, maka $\pi\left(\mathrm{x}_{\mathrm{i}}\right)=\frac{e^{g\left(x_{i}\right)}}{1+e^{g\left(x_{i}\right)}}$

Untuk menentukan estimasi parameter digunakan metode iterasi Newton Raphson yang membutuhkan turunan pertama dan turunan kedua dari fungsi likelihood, dengan fungsi likelihoodnya adalah:

$$
1(\beta)=\prod_{i=1}^{n}\left\{\pi\left(x_{i}\right)\right\}^{y_{i}}\left\{1-\pi\left(x_{i}\right)\right\}^{1-y_{i}}
$$

Sehingga fungsi ln likelihoodnya:

$$
\begin{aligned}
\mathrm{L}(\beta) & =\ln \{1(\beta)\} \\
& =\ln \left\{\prod_{i=1}^{n}\left\{\pi\left(x_{i}\right)\right\}^{y_{i}}\left\{1-\pi\left(x_{i}\right)\right\}^{1-y_{i}}\right\} \\
& =\sum_{i=1}^{n}\left[y_{i} \ln \left\{\frac{e^{g\left(x_{i}\right)}}{1+e^{g\left(x_{i}\right)}}\right\}+\left(1-y_{i}\right) \ln \left\{1-\frac{e^{g\left(x_{i}\right)}}{1+e^{g\left(x_{i}\right)}}\right\}\right] \\
& =\sum_{i=1}^{n}\left[y_{i} g\left(x_{i}\right)-\ln \left(1+e^{g\left(x_{i}\right)}\right)\right]
\end{aligned}
$$

Turunan pertama persamaan (3):

$$
\frac{\partial L(\beta)}{\partial \beta_{0}}=\sum_{i=1}^{n}\left[y_{i}-\frac{e^{g\left(x_{i}\right)}}{1+e^{g\left(x_{i}\right)}}\right]=\sum_{i=1}^{n}\left[y_{i}-\pi\left(x_{i}\right)\right]
$$


dan $\frac{\partial L(\beta)}{\partial \beta_{j}}=\sum_{i=1}^{n}\left[y_{i}-\frac{x_{j i} e^{g\left(x_{i}\right)}}{1+e^{g\left(x_{i}\right)}}\right]=\sum_{i=1}^{n} x_{j i}\left[y_{i}-\pi\left(x_{i}\right)\right]$, untuk $\mathrm{j}=1,2, \ldots, \mathrm{p}$

apabila ditulis dalam matriks berbentuk

$$
\left[\begin{array}{cccccc}
1 & 1 & \cdot & \cdot & \cdot & 1 \\
x_{11} & x_{12} & \cdot & \cdot & \cdot & x_{1 n} \\
\cdot & \cdot & & & \cdot \\
\cdot & \cdot & & & \cdot \\
\cdot & \cdot & & & \cdot \\
x_{p 1} & x_{p 2} & \cdot & \cdot & \cdot & x_{p n}
\end{array}\right]\left[\begin{array}{c}
y_{1}-\pi\left(x_{1}\right) \\
y_{2}-\pi\left(x_{2}\right) \\
\cdot \\
\cdot \\
\cdot \\
y_{n}-\pi\left(x_{n}\right)
\end{array}\right] \text { atau } \mathbf{X}^{\prime}(\mathbf{Y}-\pi(\mathbf{x}))
$$

Selanjutnya turunan kedua dari persamaan (3) adalah:

$\frac{\partial^{2} L(\beta)}{\left(\partial \beta_{0}\right)^{2}}=-\sum_{i=1}^{n}\left[\frac{e^{g\left(x_{i}\right)}\left(1+e^{g\left(x_{i}\right)}\right)-\left(e^{g\left(x_{i}\right)}\right)^{2}}{\left(1+e^{g\left(x_{i}\right)}\right)^{2}}\right]=-\sum_{i=1}^{n} \pi\left(x_{i}\right)\left[1-\pi\left(x_{i}\right)\right]$
- $\frac{\partial^{2} L(\beta)}{\partial \beta_{0} \partial \beta_{j}}=-\sum_{i=1}^{n}\left[\frac{x_{j i} e^{g\left(x_{i}\right)}\left(1+e^{g\left(x_{i}\right)}\right)-x_{j i}\left(e^{g\left(x_{i}\right)}\right)^{2}}{\left(1+e^{g\left(x_{i}\right)}\right)^{2}}\right]=-\sum_{i=1}^{n} x_{j i} \pi\left(x_{i}\right)\left[1-\pi\left(x_{i}\right)\right]$

untuk $\mathrm{j}=1,2, \ldots, \mathrm{p}$

- $\frac{\partial^{2} L(\beta)}{\partial \beta_{u} \partial \beta_{j}}=-\sum_{i=1}^{n}\left[\frac{x_{u i} x_{j i} e^{g\left(x_{i}\right)}\left(1+e^{g\left(x_{i}\right)}\right)-x_{u i} x_{j i}\left(e^{g\left(x_{i}\right)}\right)^{2}}{\left(1+e^{g\left(x_{i}\right)}\right)^{2}}\right]=-\sum_{i=1}^{n} x_{u i} x_{j i} \pi\left(x_{i}\right)\left[1-\pi\left(x_{i}\right)\right]$

untuk j, $\mathrm{u}=1,2, \ldots, \mathrm{p}$ dan $\mathrm{u} \leq \mathrm{p}$

- $\frac{\partial^{2} L(\beta)}{\left(\partial \beta_{j}\right)^{2}}=-\sum_{i=1}^{n}\left[\frac{x_{j i} x_{j i} e^{g\left(x_{i}\right)}\left(1+e^{g\left(x_{i}\right)}\right)-x_{j i} x_{j i}\left(e^{g\left(x_{i}\right)}\right)^{2}}{\left(1+e^{g\left(x_{i}\right)}\right)^{2}}\right]=-\sum_{i=1}^{n}\left(x_{j i}\right)^{2} \pi\left(x_{i}\right)\left[1-\pi\left(x_{i}\right)\right]$

untuk $\mathrm{j}=1,2, \ldots, \mathrm{p}$

Jika dinyatakan dalam bentuk matriks adalah: $\mathbf{X}^{\prime} \mathbf{V X}$

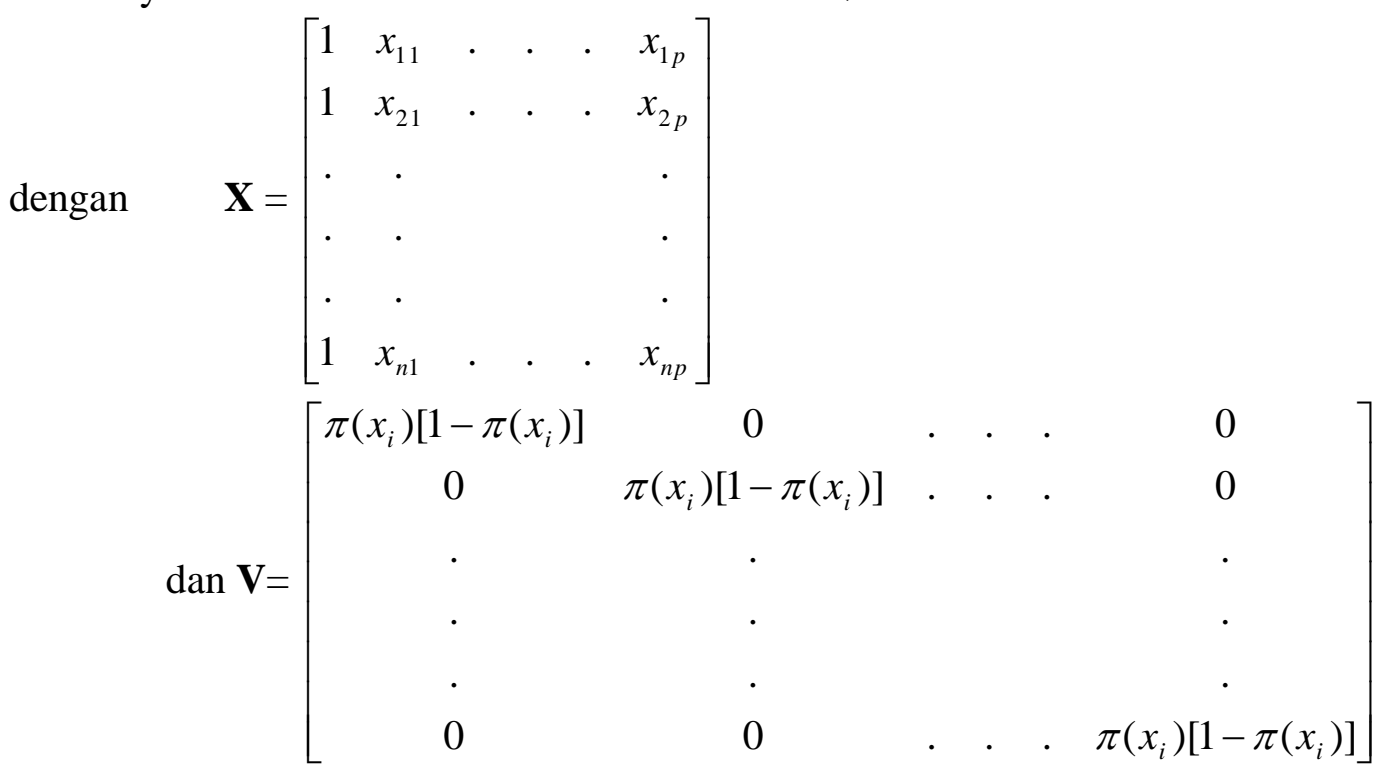


Selanjutnya dilakukan metode iterasi Newton-Raphson yang menggunakan turunan pertama dan turunan kedua dari persamaan (3):

1. Dipilih taksiran awal untuk $\beta$, misal $\hat{\beta}=0$

2. Dihitung $\mathbf{X}^{\prime}(\mathbf{Y}-\pi(\mathbf{x}))$ dan $\mathbf{X}^{\prime} \mathbf{V X}$, selanjutnya dihitung invers dari $\mathbf{X}^{\prime} \mathbf{V X}$

3. Pada setiap i+1 dihitung taksiran baru yaitu: $\hat{\beta}_{i+1}=\hat{\beta}_{i}+\left\{\mathbf{X}^{\prime} \mathbf{V X}\right\}^{-1}\left\{\mathbf{X}^{\prime}(\mathbf{Y}-\pi(\mathbf{x}))\right\}$

4. Iterasi berakhir jika diperoleh $\hat{\beta}_{i+1} \cong \hat{\beta}_{i}$

Untuk menguji signifikansi dari parameter dalam model digunakan uji rasio likelihood dan uji wald. Uji rasio likelihood digunakan untuk menguji signifikansi koefisien parameter dari model secara keseluruhan. Sedangkan uji wald digunakan untuk menguji signifikansi dari masing-masing koefisien parameter dari model.

\section{Uji rasio likelihood}

Hipotesis: $\quad \mathrm{H}_{0}: \beta_{1}=\beta_{2}=\ldots=\beta_{\mathrm{p}}=0$

$\mathrm{H}_{1}$ : paling sedikit satu $\beta_{\mathrm{j}} \neq 0$, untuk $\mathrm{j}=1,2, \ldots, \mathrm{p}$

Statistik uji: $\quad G=-2 \ln \left(\frac{\text { likelihood tan pa var iabel bebas }}{\text { likelihood dengan var iabel bebas }}\right)$

Tingkat signifikansi: $\alpha$

Kriteria uji: $\quad$ Tolak $\mathrm{H}_{0}$ jika $\mathrm{G}>\chi_{\alpha, \mathrm{p}}^{2}$ atau Sig. $<\alpha$

\section{Uji Wald}

Hipotesis: $\quad \mathrm{H}_{0}: \beta_{\mathrm{j}}=0, \mathrm{j}=1,2, \ldots, \mathrm{p}$

$$
\mathrm{H}_{1}: \beta_{\mathrm{j}} \neq 0, \mathrm{j}=1,2, \ldots, \mathrm{p}
$$

Statistik uji: $\quad \mathrm{W}_{\mathrm{j}}=\left[\frac{\hat{\beta}_{j}}{S E\left(\hat{\beta}_{j}\right)}\right]^{2}$

Tingkat signifikansi: $\alpha$

Kriteria uji: $\quad$ Tolak $\mathrm{H}_{0}$ jika $\mathrm{W}_{\mathrm{j}}>\chi_{\alpha, 1}^{2}$ atau Sig. $<\alpha$

\section{Pembahasan}

Data diperoleh dari Dinas Kesehatan Jawa Tengah, yaitu data pasien penyakit flu burung di Jawa Tengah tahun 2005 - 2008, dengan variabel respon adalah sembuh tidaknya pasien flu burung yang dikategorikan sembuh $=1$ dan meninggal $=0$, sedang variabel penjelas adalah jenis kelamin (laki-laki $=1$, perempuan $=0$ ), usia $(\leq 20$ tahun $=1$, $>20$ tahun $=0$ ), epidemiologi (ada unggas mati $=1$, kontak dengan unggas $=2$, tidak ada kontak $=3$ ) dan kasus ( suspect $=1$, konfirmasi $=0$ ). Kasus disini dikategorikan menjadi 2 karena data pada Dinas Kesehatan Jawa Tengah tidak terdapat kasus probable. Diasumsikan semua pasien memperoleh pengobatan yang sama.

Sebelum dibentuk model dilakukan uji independen untuk mengetahui apakah ada hubungan antara sembuh tidaknya pasien flu burung dengan jenis kelamin, usia, epidemiologi dan kasus dengan hipotesa sebagai berikut:

$\mathrm{H}_{0}$ : Tidak ada hubungan antara variabel respon dan variabel prediktor

$\mathrm{H}_{1}$ : Ada hubungan antara variabel respon dan variabel prediktor 
Statistik uji: $\chi^{2}$ hitung $=\sum_{i=1}^{r} \sum_{j=1}^{c}\left[\frac{\left(O_{i j}-E_{i j}\right)^{2}}{E_{i j}}\right]$

dengan: $\mathrm{O}_{\mathrm{ij}}=$ nilai observasi baris ke-i dan kolom ke-j

$\mathrm{E}_{\mathrm{ij}}=$ nilai yang diharapkan baris ke-i dan kolom ke-j

Tingkat signifikansi: $\alpha=0,05$

Kriteria uji: Tolak $\mathrm{H}_{0}$ jika $\chi_{\text {hitung }}^{2}>\chi_{\alpha,(\mathrm{c}-1)(\mathrm{r}-1)}^{2}$ atau Sig. $<\alpha$

Dari pengolahan data dengan menggunakan SPSS 13 diperoleh hasil seperti terlihat pada Tabel 1, di bawah ini.

Tabel 1. Uji Independen Variabel Respon dan Variabel Prediktor

\begin{tabular}{|l|c|c|l|}
\hline \multicolumn{1}{|c|}{$\begin{array}{c}\text { Variabel Respon * Variabel } \\
\text { Penjelas }\end{array}$} & Nilai Chi-square & Signifikan & Keputusan \\
\hline Sembuh * Jenis Kelamin & 0,422 & 0,516 & Ho diterima \\
\hline Sembuh * Epidemiologi & 11,430 & 0,003 & Ho ditolak \\
\hline Sembuh * Kasus & 23,690 & 0,000 & Ho ditolak \\
\hline Sembuh * Usia & 0,865 & 0,352 & Ho diterima \\
\hline
\end{tabular}

Dari Tabel 1, terlihat bahwa antara variabel sembuh dan jenis kelamin serta usia tidak ada hubungan, sedangkan antara variabel sembuh dan epidemiologi serta kasus terdapat hubungan, sehingga dari 4 variabel penjelas yang akan dibentuk model regresi logistik biner hanya 2 variabel saja, yaitu epidemiologi dan kasus. Jadi yang mempengaruhi kesembuhan pasien penyakit flu burung adalah epidemiologi dan kasus. Dengan menggunakan SPSS 13 diperoleh model awal regresi logistik biner:

$$
\ln \left(\frac{\pi\left(x_{i}\right)}{1-\pi\left(x_{i}\right)}\right)=-1,721+3,667 \text { kasus }+0,129 \text { epi(1) - 1,446 epi(2) }
$$

dengan $\pi\left(\mathrm{x}_{\mathrm{i}}\right)=\frac{e^{-1,721+3,667 \text { kasus }+0,129 \text { epi(1)-1,446epi(2) }}}{1+e^{-1,721+3,667 \text { kasus }+0,129 e p(1)-1,446 \text { epi }(2)}}$

Selanjutnya dilakukan uji signifikansi model

- Uji rasio likelihood:

Hipotesis: $\mathrm{H}_{0}: \beta_{1}=\beta_{2}=\beta_{3}=0$

$\mathrm{H}_{1}$ : paling sedikit satu $\beta_{\mathrm{j}} \neq 0$, untuk $\mathrm{j}=1,2,3$

Statistik uji: $\mathrm{G}=-2 \ln \left(\frac{\text { likelihood } \tan p a \text { var iabel bebas }}{\text { likelihood dengan variabel bebas }}\right)$

$$
\begin{aligned}
& =111,598-80,983 \\
& =30,615
\end{aligned}
$$

Tingkat signifikansi: $\alpha=0,05$

Kriteria uji: Tolak $\mathrm{H}_{0}$, jika $\mathrm{G}>\chi_{0,05 ; 3}^{2}$ atau Sig. $<0,05$

Keputusan : karena $\mathrm{G}=30,615>\chi_{0,05 ; 3}^{2}=0,35$, maka $\mathrm{H}_{0}$ ditolak sehingga koefisien parameter model signifikan. 
- Uji Wald

Hipotesis: $\mathrm{H}_{0}: \beta_{\mathrm{j}}=0, \mathrm{j}=1,2,3$

$\mathrm{H}_{1}: \beta_{\mathrm{j}} \neq 0, \mathrm{j}=1,2,3$

Statistik uji: $\mathrm{W}_{\mathrm{j}}=\left[\frac{\hat{\beta}_{j}}{\operatorname{SE}\left(\hat{\beta}_{j}\right)}\right]^{2}$

Tingkat signifikansi: $\alpha=0,05$

Kriteria uji: Tolak $\mathrm{H}_{0}$ jika $\mathrm{W}_{\mathrm{j}}>\chi_{0,05 ; 1}^{2}$ atau Sig. $<0,05$

Dengan menggunakan SPSS 13 diperoleh hasil seperti terlihat pada Tabel 2.

Tabel 2. Uji Wald Variabel Penjelas

\begin{tabular}{|l|c|c|c|l|}
\hline \multicolumn{1}{|c|}{ Variabel Penjelas } & Koefisien & Nilai Wald & Signifikan & \multicolumn{1}{|c|}{ Keputusan } \\
\hline Epidemiologi(1) & 0,129 & 0,022 & 0,883 & Ho diterima \\
\hline Epidemiologi $(2)$ & $-1,446$ & 4,025 & 0,045 & Ho ditolak \\
\hline Kasus & 3,667 & 10,112 & 0,001 & Ho ditolak \\
\hline
\end{tabular}

Dari Tabel 2, terlihat bahwa koefisien epidemiologi(1) tidak signifikan, sedangkan koefisien epidemiologi(2) dan kasus adalah signifikan.

Sehingga diperoleh model akhir regresi logistik biner adalah:

$\ln \left(\frac{\pi\left(x_{i}\right)}{1-\pi\left(x_{i}\right)}\right)=-1,721+3,667$ kasus $-1,446$ epidemio(2)

dengan $\pi\left(\mathrm{x}_{\mathrm{i}}\right)=\frac{e^{-1,721+3,667 k a s u s-1,446 e p i(2)}}{1+e^{-1,721+3,667 k a s u s-1,446 \text { epi }(2)}}$

Jika seorang pasien flu burung termasuk kasus konfirmasi dan ada unggas mati, maka peluangnya untuk sembuh adalah:

$$
\pi\left(\mathrm{x}_{\mathrm{i}}\right)=\frac{e^{-1,721}}{1+e^{-1,721}}=0,152
$$

dan peluangnya untuk meninggal adalah: $1-\pi\left(\mathrm{x}_{\mathrm{i}}\right)=0,848$.

Jika seorang pasien flu burung termasuk kasus konfirmasi dan ada kontak dengan unggas, maka peluangnya untuk sembuh adalah:

$$
\pi\left(\mathrm{x}_{\mathrm{i}}\right)=\frac{e^{-1,72 \mathrm{-1}, 446}}{1+e^{-1,721-1,446}}=0,04
$$

dan peluangnya untuk meninggal adalah: $1-\pi\left(\mathrm{x}_{\mathrm{i}}\right)=0,96$.

Jika seorang pasien flu burung termasuk kasus konfirmasi dan tidak ada kontak dengan unggas, maka peluangnya untuk sembuh adalah:

$$
\pi\left(\mathrm{x}_{\mathrm{i}}\right)=\frac{e^{-1,721}}{1+e^{-1,721}}=0,152
$$

dan peluangnya untuk meninggal adalah: $1-\pi\left(x_{i}\right)=0,848$.

Untuk estimasi peluang selengkapnya dapat dilihat pada Tabel 3 . 
Tabel 3. Estimasi Peluang Kesembuhan Pasien Penyakit Flu Burung Menurut Kasus dan Epidemiologi

\begin{tabular}{|c|l|c|c|}
\hline Kasus & \multicolumn{1}{|c|}{ Epidemiologi } & Sembuh & Meninggal \\
\hline \multirow{4}{*}{ Suspect } & Ada unggas mati & 0,875 & 0,125 \\
\cline { 2 - 4 } & Kontak dengan unggas & 0,662 & 0,378 \\
\cline { 2 - 4 } & Tidak ada kontak & 0,875 & 0,125 \\
\hline \multirow{3}{*}{ Konfirmasi } & Ada unggas mati & 0,152 & 0,848 \\
\cline { 2 - 4 } & Kontak dengan unggas & 0,04 & 0,96 \\
\cline { 2 - 4 } & Tidak ada kontak & 0,152 & 0,848 \\
\hline
\end{tabular}

Dari Tabel 3 terlihat bahwa seseorang yang termasuk kasus suspect peluangnya untuk sembuh lebih besar daripada meninggal, sedangkan seseorang yang termasuk kasus konfirmasi peluangnya untuk sembuh lebih kecil daripada meninggal. Selain itu dengan menggunakan koefisien variabel penjelas yang ada pada Tabel 2 , untuk $\mathrm{e}^{3,667}=39,139$ berarti resiko seseorang yang termasuk kasus suspect untuk dapat sembuh adalah 39,139 kali seseorang yang termasuk kasus konfirmasi, berarti seseorang yang termasuk kasus suspect resikonya untuk sembuh adalah lebih besar daripada seseorang yang termasuk kasus konfirmasi dan untuk $\mathrm{e}^{-1,446}=0,236$ berarti resiko seseorang yang ada kontak dengan unggas untuk dapat sembuh adalah 0,236 kali seseorang yang tidak ada kontak, berarti seseorang yang ada kontak dengan unggas resikonya untuk sembuh adalah lebih kecil daripada seseorang yang tidak ada kontak.

\section{Kesimpulan}

a. Kesembuhan pasien penyakit flu burung dipengaruhi oleh epidemiologi dan kasus

b. Peluangnya seorang pasien flu burung yang termasuk kasus suspect untuk sembuh lebih besar daripada meninggal, sedangkan seseorang yang termasuk kasus konfirmasi peluangnya untuk sembuh lebih kecil daripada meninggal

c. Resiko seseorang yang termasuk kasus suspect untuk dapat sembuh lebih besar daripada seseorang yang termasuk kasus konfirmasi

d. Resiko seseorang yang ada kontak dengan unggas untuk dapat sembuh lebih kecil daripada seseorang yang tidak ada kontak

\section{DAFTAR PUSTAKA}

1. Agresti, A., Categorical Data Analysis, Second Edition, John Wiley \& Sons, New York, 2002 .

2. Departemen Kesehatan, Flu Burung, Badan Penelitian dan Pengembangan Kesehatan, Depkes RI, URL : http://www.litbang.depkes.go.id (diakses 1 Mei 2009).

3. Departemen Kesehatan, Waspada Flu Burung, Departemen Kesehatan Republik Indonesia, URL : http://www.depkes.go.id (diakses 1 Mei 2009).

4. Hosmer, D.W. and Lemeshow, S., Applied Logistic Regression, John Wiley \& Sons, Canada, 1989.

5. Nachrowi, N.D., Penggunaan Teknik Ekonometrika, PT. Raja Grafindo Persada, Jakarta, 2002.

6. __ Flu Burung, Wikipedia, http://id.wikipedia.org (diakses 1 Mei 2009). 